\title{
Dynamics of territorial production in situated and community projects
}

\author{
Manfredo Manfredini (lead author), Uwe Rieger \\ University of Auckland, New Zealand \\ School of Architecture and Planning \\ m.manfredini@auckland.ac.nz | u.rieger@auckland.ac.nz
}

This section considers forms of collaboration in situated and community projects embedded in important spatial transformation processes in New Zealand cities. It aims to shed light on specific combinations of material and semantic aspects characterising the relation between people and their environment. Contributions focus on participative urban transformations. The essays that follow concentrate on the dynamics of territorial production of associations between multiple actors belonging both to civil society and constituted authority. Their authors were directly engaged in the processes that are reported and conceptualised, thereby offering evidence gained through direct hands-on experience. Some of the investigations use case studies that are conspicuous examples of the recent post-traumatic urban development stemming from the Canterbury earthquakes of 2010-20I I. More precisely, these cases belong to the early phases of the programmes of the Christchurch recovery or the Wellington seismic prevention. The relevance of these experiences for the scope of this study lies in the unprecedented height of public engagement at local, national and international levels, a commitment reached also due to the high impact, both emotional and concrete, that affected the entire society.

The articles of this section have been collated to document projects that provide complementary contributions to the discourse on urbanism in the area that addresses contemporary problems affecting public space, social infrastructure and power relations in network developments. The common ground of authors' approaches is the use of an empirically grounded spatio-social perspective. This implies establishing an intimate relation between theoretical work and empirical practice, not only to entirely appreciate the contribution to theory of a particular phenomenon and vice versa, but, more importantly, to align the nature of the research practice to that of the studied phenomenon. This approach develops ad-hoc mixed research methodologies that disentangle, while maintaining associated, complex and concurrent aspects of each process's spatial production: the conceived, lived and represented dimensions. 
This form of investigation on spatially situated conditions is relevant to the articulation of the discourse descending from major research traditions: firstly, from the work on space of Henry Lefebvre;' secondly, from actor-network and assemblage theories; ${ }^{2}$ and, thirdly, from their related development on territoriology. ${ }^{3}$ More specifically, with reference to the latter, these studies can provide important support to Andrea Brighenti's proposition that our age is facing an "unpredictable multiplication, interpenetration and ongoing production" of territories. ${ }^{4}$ Key in the discussion are indeed the peculiar forms, dynamics and effects generated by each situated aggregation of associative systems; each form, dynamic and effect is seen as an expression of chains of relations reflecting the fundamental tension, well described by Doreen Massey, ${ }^{5}$ between territorial grounding and relational responsiveness.

The discussion on territorial behaviours, particularly articulated by Bennett and Moore, unravels relevant patterns regarding strategies of occupation, tactics of appropriation, and effects of association and spatial control management. It focuses on the dynamics of their socio-spatial constitutive processes, documenting their progressive expansion from individual acts and actors into multidimensional assemblages of practices and apparatuses with heterochronic paces. The practices and apparatuses are analysed to elicit the irreducible specificity of each actor - or to use Latour terminology, actant ${ }^{6}-$

\footnotetext{
' Henri Lefebvre, The Critique of Everyday Life, Volume I, John Moore trans. (London, England: Verso, 199I); The Production of Space (Oxford, England: Blackwell, 199I); Writings on cities (Cambridge, MA: Blackwell, 1996), The urban revolution, R. Bononno, Trans. (Minneapolis: University of Minnesota Press, 2003), Rhythmanalysis, Space, Time and Everyday Life (London, England, and New York, NY: Continuum, 2004). Edward Soja, Postmodern Geographies: The Reassertion of Space in Critical Social Theory (London, England: Verso Press, 1989); Postmetropolis: Critical Studies of Cities and Regions (Oxford; Malden, Mass.: Basil Blackwell, 2000). Mark Purcell, "Excavating Lefebvre: The right to the city and its urban politics of the inhabitant," Geojournal, 58, 2-3 (2002): 99-108; "Possible Worlds: Henri Lefebvre and the Right to the City," Journal of Urban Affairs, 36, I (2013): I4I-I54.

2 Bruno Latour, "On recalling ANT”, Sociological Review 46 (1998): 15-25; Reassembling the Social: An introduction to Actor-Network-Theory (New York: Oxford University Press, 2005). lohn Law, "Actor Network Theory and Material Semiotics," in The New Blackwell Companion to Social Theory, ed. B. S. Turner (Chichester, England: John Wiley and Sons, 2009): I4I-I58. Jonathan Murdoch, "The Spaces of Actor-Network Theory,” Geoforum 29 (1998): 357-74. Gilles Deleuze and Félix Guattari, Rhizome (Paris: Editions de Minuit, 1976); Anti-Oedipus, (Minneapolis: University of Minnesota Press, 1983). Ignacio Farías and Thomas Bender, eds., Urban Assemblages: How Actor-Network Theory Changes Urban Studies (London: Routledge, 2010). Ben Anderson and Colin McFarlane, eds., "Assemblage and Geography," Area 43 (20I I): I24-64. Colin McFarlane, Learning the City: Knowledge and Translocal Assemblage (Oxford: Wiley-Blackwell, 201 I).

${ }^{3}$ Mattias Kärrholm, Retailising Space: Architecture, Retail and the Territorialisation of Public Space (Surrey, England: Ashgate, 20I2). Andrea M. Brighenti, “Mobilizing Territories, Territorializing Mobilities”, Sociologica I (2014): I-I6. Peter Merriman, "Human Geography Without Time-Space," Transactions of the Institute of British Geographers 37, n.I (2012): I3-27

${ }^{4}$ Brighenti, “Mobilizing Territories, Territorializing Mobilities", 3.

${ }^{5}$ Doreen Massey, World City (Cambridge, England: Polity Press, 2007).

${ }^{6}$ Latour, Reassembling the social: An introduction to actor-network-theory, 7I.
} 
in its physical (devices, materials and objects), social (routines, bonds, alliances and conflicts) and semantic (languages, signs and representations) aspects.

The actants are also explored through their permanent involvement in the establishment and re-establishment of repeated and ad hoc, confined and translocal, tangible and intangible "chains of activation and reactivity."7 The evaluation of effectiveness of these chains of relations centres on their capacity to shape, organise and transform the environment.

Particularly relevant in the background of this discussion is the contention on the ontogenetic capacity of space and its correlative right to the city ${ }^{8}$ that results from historically specific material, conceptual and quotidian practices. ${ }^{9}$ This is a tenet, recently adopted by the United Nations' New Urban Agenda for a sustainable urban development, ${ }^{10}$ that advocates a pluralist and inclusive public sphere as an effective antidote to the progressive fragmentation of the social, cultural and environmental body of the city, only by establishing spatialities of equitable, emancipatory and agonistic relationships." This also includes the call to provide studies and evidence of concrete instances where practices exercising the freedom to "make and remake ourselves and our cities" 12 produce substantive tangible effects for the reconstitution of the urban integrity from the "seeds" present in its own fabric.

The projects presented respond to right to the city call, being instances countering the homogenisation and spatio-behavioural systems of control, often instituted with citizens' complicity by leading forces of the post-consumerist society. ${ }^{13}$ These projects oppose the progressive privatisation of socially relevant public spaces and the related commodification of life quality. ${ }^{14}$ With the support given to multiple and often

\footnotetext{
${ }^{7}$ Brighenti, "Mobilizing Territories, Territorializing Mobilities", 20.

${ }^{8}$ Robert Park, On Social Control and Collective Behavior (Chicago: University of Chicago Press, 1967): 3. Henri Lefebvre, Writings on Cities (Cambridge, MA: Blackwell, 1996). David Harvey, "The Right to the City", New Left Review 53 (2008): 23-40.

${ }^{9}$ Henri Lefebvre, The Critique of Everyday Life.

10 United Nations, New Urban Agenda: Quito Declaration on Sustainable Cities and Human Settlements for All, document adopted at United Nations Conference on Housing and Sustainable Urban Development - Habitat III Quito, Ecuador, October 2016.

" Chantal Mouffe, "Deliberative Democracy or Agonistic Pluralism?," Social Research 66, n. 3 (1999): 745-758; "Public Spaces and Democratic Politics", in Highrise-Common Ground. Art and the Amsterdam Zuidas Area, ed. J. Boomgaard (Amsterdam: Valiz, 2008): I35-I56. Dana Villa, "Postmodernism and the Public Sphere", American Political Science Review 86 (1992): 7I 2-2I.

12 David Harvey, "The Right to the City", 23.

${ }^{13}$ Steven Miles, "The Neoliberal City and the Pro-Active Complicity of the Citizen Consumer", Journal of Consumer Culture I2, n. 2 (2012): 216-230.

14 Tridib Banerjee, "The Future of Public Space: Beyond Invented Streets and Reinvented Places", Journal of the American Planning Association 67, n. I (200I): 9-24. Anna Minton, Ground Control: Fear and Happiness in the Twenty-First Century City (London: Penguin, 2009). Manfredo Manfredini and Ross Jenner, "The Virtual Public Thing: De-Re-Territorialisations of Public Space Through Shopping in Auckland's Urban Space", Interstices: Journal of Architecture and Related Arts 16 (2015): 75-8I. Manfredo Manfredini, Xin Tian, Ross Jenner, and Asu Besgen, "Transductive Urbanism" A Method for the Analysis of the Relational Infrastructure of Malled Metropolitan Centres in Auckland, New Zealand,
} 
contradictory and conflicting parties, they guarantee the direct involvement and permanent participation of all stakeholders, fostering inclusion, autonomy and social interplay. Their concurrent action in interacting networks institute mechanisms of territorial production that establish open, anti-hierarchical and participatory relational systems.

According to their characteristics, three key types of institutionalised forms of territorial production have been identified as processes triggered by events, grassroots movements and established organisations.

The first type includes large, coral public events, such as Christchurch's Festa, discussed by McPherson and Pretty. They are purpose-made, self-organising systems where territories are strongly appropriated, but little association is produced, due to the ephemeral nature of the events. Their spatial production relies mainly on daily tactical moves, often with low-risk ephemeral dynamics that involve multiple actors with very diverse social, cultural, economic and institutional backgrounds. These systems have typically short-term lifespans, since they are mainly conceived as temporary events of exceptional kind. They articulate forms of synchronisation with short-term rhythms of basic bodily species, such as hunger, fatigue and pace, but also of emotional kinds, such as those related to drivers, concerning a sense of belonging, accomplishment, excitement and control. Their limited duration makes them particularly suited to festive celebratory events centred on communication, with concentration in multiple simultaneous manifestations located in nodal places of easy access. These places are conceived as platforms to catalyse creative forces present in the locale and amplify their expression to widen their public reception.

The second type includes initiatives by grassroots organisations and intermediate nongovernmental organisations, such as Gap Filler, discussed by Bennett and Moore. These are place-specific, incremental semi-structured systems based on processes of strong association of territories and networks. Their spatial production is based on combinations of strategic conceptions and tactical moves. Their action is triggered and led by an agency (often an existing structured organisation) and is based on constant active participation of local individuals and groups. These systems are typically based on everyday practices and pop-up/incremental dynamics with low capital investments and mid-term lifespans. They are composed by assembling small-size elements and systems of provisional or medium-term duration that are distributed throughout urban areas. They articulate forms of synchronisation with medium-term rhythms suitable for the incremental dynamics of loose voluntary associations and grassroots movements engaged in the reconstitution and recombination of vital social networks after major traumatic events. These systems are synchronised with daily and weekly routines and aligned with the rhythms of public life, relational activity, recreation, and communicative/political action of specific habitats.

The third type includes institutions created by either governmental or nongovernmental organisations, such as territorial social units, like Māori organisations,

Athens Journal of Architecture , in print (pre-published online on I ${ }^{\text {st }}$ February 20I7). Edward Soja, Seeking Spatial Justice (Minneapolis: University of Minnesota Press, 2010). 
engaged by Prendergast and Brown in their article addressing issues of New Zealand cultural communities. These institutions form stable, consolidated, sole and highly structured systems based on processes of strong association with cultural territories and networks. Their spatial production is based on strategic conceptions. Their action is typically coordinated by a leading agency (often an existing structured organisation, such as a governmental department) and aimed at constituting platforms for the participation and integration of local and foreign individuals and groups. They are composed of large-scale and permanent structures that require long-term and highplanning and management capacity. Their setup and operation, which require high capital investment, are synchronised with multiple routines of institutions, operators and the public.

Although these types of institutionalised forms of territorial production, through situated and community projects, have different stakeholders and dynamics, they complementarily contribute to a development of their socio-spatial locale that integrates cognitive, normative, and aesthetic dimensions of the lifeworld and systems paradigms. This is primarily due to the open nature of their established chains of associations and their concrete acting towards a radically democratic social model based on equality, freedom, and difference. These are organisations based on bottomup decision-making processes, often constituted by consolidated non-governmental organisations, such as grassroots activist groups, and educational and cultural institutions, such as tertiary education establishments. Most of them have been generated by the formalisation of latent and informal agencies (both of individual and networked actors) developed either peripherally or externally to conventional governance structures. They often include structured and emergent small local networks that reach critical mass through linkages at a global level. They are aggregations that often suffer the marginalisation perpetuated by the combined effect of the downward power structures of leading authorities and pervasive economics of transnational organisations, as described by Sharon Zukin in Landscape of Power ${ }^{15}$ and Steven and Malcolm Miles's Consuming Cities. ${ }^{16}$ Whilst, when excluded, they tend to develop antagonist patterns in the form of heterotopic spaces of resistance and heterological spheres of thought, when they are situated in conditions of integration they are able to effectively contribute to the actuation of invaluable conditions that Lefebvre has described as maximal differentiation. ${ }^{17}$

This form of differentiation is a particular condition that, implementing participated organisational formats, promotes engagement and mobilisation within instituted authorities. Its uptake can trigger unpredictable, yet effective, processes of reframing and redefining of non-responsive, externally imposed and obsolete systems.

Maximal differentiation processes can create a productive realm where diversity can grow free from oppressive power in spaces of open exchange and confrontation. Its

\footnotetext{
${ }^{15}$ Sharon Zukin, Landscapes of Power: From Detroit to Disney World (Berkeley: University of California Press, | 1991).

${ }^{16}$ Steve Miles and Malcolm Miles, Consuming Cities, (New York: Palgrave Macmillan, 2004).

${ }^{17}$ Henri Lefebvre, The Critique of Everyday Life.
} 
Chapter 3 - Introduction

adoption is crucial to enhance local communities' empowerment, both at individual and network levels, foster genuine creative production, and preserve cultural expressions produced in their own socially relevant context.

\section{To cite this article:}

Manfredini, M., Rieger, U. (2017), Dynamics of territorial production in situated and community projects, The Journal of Public Space, 2(3), Special Issue, I29-I34, DOI: 10.5204/jps.v2i3.I2I

This article has been accepted for publication in The Journal of Public Space. Please see the Editorial Policies under the 'About' section of the journal website for further information.

This work is licensed under a Creative Commons Attribution - Non Commercial 4.0 International License https://creativecommons.org/licenses/by-nc/4.0/ 